\title{
PENGARUH PEMBELAJARAN ONLINE BERBASIS WEBSITE ELEARNING MADRASAH TERHADAP HASIL BELAJAR FISIKA SISWA KELAS X IPA MAN 2 KOTA PALU
}

\author{
Mohammad Djamil M Nur
}

Kantor Wilayah Kementerian Agama Provinsi Sulawesi Tengah abqary1234@gmail.com

Abstract:

This research's aim was to determine how much the influence of Online Learning based on Website E-learning Madrasah on the Physics Learning Outcomes of Class X IPA MAN 2 Kota Palu Academic Year 2020/2021 and to know what obstacles were felt by teachers and students when conducting online teaching and learning activities during the covid-19 pandemic. Respondents were students of class X IPA1 MAN 2 Kota Palu because they have had internet facilities, computers and gadgets. This study used a quantitative method with data testing using SPSS 25. Data were obtained through filling out questionnaires by students and also conducted interviews to the teachers as supporting data. The tests conducting were validity, reliability, and $R$ square test to find out how much the influence of online learning based on website e-learning madrasah on students' physics learning outcomes. The results showed that Online learning based on website e-learning madrasah had a significant effect on student physics learning outcomes about $85,7 \%$. From the results of the SPSS test, the value of sig.(2-tailed) for each variable $X$ and $Y$ was $<0.005$. Judging from the value of $r_{\text {count }}$ and $r_{\text {table, }}$ the result was that the value of $r_{\text {count }}>r_{\text {table. }}$. The $r_{\text {table }}$ value of 0,3291 was obtained from the $N$ value of $36-2=34$. The number 34 has an $r$ table value of 0,3291 . The results of the reliability test could be seen that overall, the $X$ and $Y$ variables had Cronbach's alpha values $>0.06$. Online Learning based on website e-learning madrasah is able to help the education world, particularly in madrasah during the Covid 19 pandemic. According to the homeroom teacher, student learning outcomes tend to be stable and do not decrease even though learning is conducted by online.

Keywords: website e-learning madrasah; physics learning outcomes 


\section{Abstrak}

Penelitian ini bertujuan untuk mengetahui seberapa besar pengaruh Pembelajaran Online berbasis Website Elearning Madrasah Terhadap Hasil Belajar Fisika Siswa Kelas X IPA MAN 2 Kota Palu Tahun Ajaran 2020/2021. Serta untuk mengetahui apa saja kendala dan hambatan yang dirasakan guru maupun siswa saat melakukan kegiatan belajar mengajar online selama masa pandemic covid-19 ini. Responden adalah siswa kelas X IPA1 MAN 2 Kota Palu karena mereka telah memiliki fasilitas internet, komputer dan gadget. Penelitian ini menggunakan metode kuantitatif dengan uji data menggunakan spss 25. Data diperoleh melalui pengisian kuesioner oleh siswa dan juga dilakukan wawancara oleh guru sebagai data pendukung. Uji yang dilakukan yaitu validitas, reabilitas, dan uji $\mathrm{R}$ square untuk mencari seberapa besar pengaruh pembelajaran online berbasis website elearning madrasah terhadap hasil belajar fisika siswa. Hasil penelitian menunjukkan bahwa pembelajaran online berbasis website elearning madrasah mempunyai pengaruh yang signifikan terhadap hasil belajar fisika siswa sebanyak 85,7\%. Dari hasil pengujian spss bahwa nilai sig.(2-tailed) setiap variabel $\mathrm{X}$ dan variabel $\mathrm{Y}$ adalah $<0,005$. Dilihat dari nilai rhitung dan $\mathrm{r}_{\text {tabel }}$ didapat hasil bahwa nilai $r_{\text {hitung }}>r_{\text {tabel. }}$ Nilai $r_{\text {tabel }}$ 0,3291 diperoleh dari nilai N 36-2=34. Angka 34 mempunyai nilai $r$ tabel 0,3291. Hasil uji reliabilitas dapat diketahui bahwa secara keseluruhan variabel $\mathrm{X}$ dan Y memiliki nilai cronbach's alpha $>0,06$. Pembelajaran online berbasis website elearning madrasah mampu menjadi penolong dunia pendidikan khususnya di madrasah pada masa pandemi Covid 19 ini. Menurut penuturan wali kelas juga hasil belajar siswa cenderung stabil dan tidak mengalami penurunan walaupun pembelajaran dilakukan dengan online.

Kata kunci: website e-learning madrasah; hasil belajar fisika 


\section{Pendahuluan}

Saat merebaknya Covid-19 atau corona pada awal tahun 2020, kehebohan mulai menyeruak secara berangsur yang bahkan menjangkau seluruh dunia. Kehebohan ini dipicu oleh banyaknya jumlah korban dalam waktu relatif singkat disertai kegamangan semua pihak menghadapi Covid-19. Virus ini pertama kali ditemukan di Wuhan China yang kemudian mulai menular serta menyebar ke berbagai negara termasuk Indonesia. ${ }^{1}$

Berbagai negara kemudian mulai menerapkan Protokol Covid-19 sesuai dengan anjuran World Health Organization (WHO), mulai dari cuci tangan, tidak berkumpul/melakukan pertemuan, menjaga jarak, membatasi keluar rumah bahkan dilakukan langkah isolasi mulai isolasi mandiri perorangan, komunitas, bahkan seluruh kota (mulai dari Pembatasan Sosial Berskala Besar/PSBB sampai lock down). Sebagai akibatnya banyak kantor baik pemerintah maupun swasta yang kemudian menerapkan skema bekerja dari rumah (Working from Home/WFH).

Munculnya pandemi virus Covid-19 juga memberikan dampak yang sangat besar pada bidang pendidikan, sehingga menuntut perlunya dilakukan perubahan metode dalam mengajar. Siswa dan guru diajak untuk melakukan proses belajar mengajar melalui metode jarak jauh. Pandemi yang melanda selama hampir satu tahun ini membuat sekolahsekolah diliburkan. Pembelajaran jarak jauh ini dilakukan pada seluruh lembaga pendidikan mulai dari Pendidikan Dasar hingga Perguruan Tinggi. Menurut data Organisasi Pendidikan, Keilmuan, dan Kebudayaan PBB (UNESCO), sejumlah 209,5 juta siswa di seluruh dunia yang

${ }^{1}$ Jeffrey Payung Langi, "Pengaruh Pembelajaran Fisika Secara Online Berbasis Zoom Meeting Terhadap Hasil Belajar Mahasiswa", Vol.16 No.2, (Maluku: Jurnal Syntax Admiration, 2020), h. 86 
aktivitas belajarnya terganggu akibat sekolah yang ditutup selama masa pandemi. $^{2}$

Kegiatan belajar mengajar yang semula dilakukan secara tatap muka di sekolah, harus dialihkan dari rumah masing-masing melalui berbagai aplikasi virtual. Para siswa dan guru harus beradaptasi agar bisa membiasakan diri melakukan kegiatan belajar mengajar secara daring (online). Hal ini sudah tentu mendatangkan efek positif maupun negatif bagi siswa ataupun guru yang mengakbatkan perlunya banyak dilakukan pembenahan dalam proses.

Pembelajaran jarak jauh ini dialihkan dengan pembelajaran online atau e-learning. Menurut Prasojo dan Riyanto ${ }^{3}$, e-learning sebuah istilah yang tidak asing pada pembelajaran berbasis online yang di jembatani oleh kecanggihan internet dan memerlukan media sosial untuk membantu menyajikan materi pembelajaran serta membutuhkan fasilitas komunikasi dalam bertukar informasi satu sama lain.

Pembelajaran online pada pelaksanaannya membutuhkan internet, yang berasal dari bahasa latin inter yang berarti "antara". Internet menghubungkan berbagai jaringan yang tidak saling bergantung satu sama lain sehingga mereka dapat berkomunikasi pada masing-masing jaringan. Internet adalah jaringan komunikasi global yang terbuka dan menghubungkan ribuan jaringan komputer, baik melalui koneksi dial up atau media lain yang menawarkan akses yang bermacam-macam. Fungsi

${ }^{2}$ Agus Purwanto dkk, "Studi Eksploratif Dampak Pandemi COVID-19 Terhadap Proses Pembelajaran Online di Sekolah Dasar", Journal of Education, Phychology and Counseling, Vol 2 No. 1 2020, h.2

3 Dini Oktarika, Pengaruh Pembelajaran Menggunakan Media E-Learning Terhadap Minat Belajar Mahasiswa Pada Mata Kuliah E-Learning Di Program Studi P.TIK, Jurnal Pendidikan Informatika dan Sains, Vol 4 No. 1 2015, h.18 
internet adalah menyediakan suatu sarana jaringan yang memiliki standarisasi prosedur jaringan sehingga dapat saling bertukar informasi. ${ }^{4}$

Pembelajaran online juga membutuhkan dukungan perangkatperangkat mobile seperti telepon pintar, tablet dan laptop yang dapat digunakan untuk mengakses informasi dimana saja dan kapan saja. Penggunaan teknologi mobile memiliki kontribusi besar di dunia pendidikan, termasuk di dalamnya adalah pencapaian tujuan pembelajaran jarak jauh. Belajar online bersifat fleksibel dan lebih mudah diakses. Namun, di sisi lain metode ini juga mengurangi interaksi antara siswa dan guru. Keadaan seperti ini menuntut para guru untuk lebih selektif dan kreatif dalam memilih metode apa yang akan digunakan dan diterapkan kepada siswa, sehingga siswa tidak merasa cepat bosan ketika menerima materi dan mengerjakan tugas-tugas yang diberikan. Ada beberapa aplikasi online yang bisa digunakan untuk membantu dan mempermudah para guru dalam meyampaikan materi kepada siswa antara lain Whatshapp, Moodle, Google Clasroom, Quizizz dan Elearning Madrasah. Hal ini tentunya tidak mudah dan tidak seefektif dengan belajar secara langsung (tatap muka). Namun, demi alasan kesehatan dan meminimalisir terbentuknya klaster baru penyebaran covid-19 mau tidak mau kegiatan ini harus dilakukan.

Menurut Dini Oktarika ${ }^{5}$, e-learning sebuah istilah yang tidak asing pada pembelajaran berbasis online yang di jembatani oleh kecanggihan internet dan memerlukan media sosial untuk membantu menyajikan materi pembelajaran serta membutuhkan fasilitas komunikasi dalam bertukar informasi satu sama lain. Tentu pembelajaran online ini

\footnotetext{
${ }^{4}$ Kompri. Belajar dan Faktor-Faktor yang Mempengaruhinya,(Yogyakarta: Media Akademi, 2017), h.100.

${ }^{5}$ Oktarika, Pengaruh..., h. 18
} 
tidak mudah dilakukan bagi siswa yang telah terbiasa belajar, berinteraksi bersama dengan teman-teman dan gurunya di sekolah. Dengan pembelajaran online tersebut, dukungan dari orang tua sangat dibutuhkan karena mereka sendiri yang akan mendampingi anaknya selama pembelajaran online berlangsung agar anak mengikuti proses pembelajaran dengan baik.

Aplikasi Website ELearning Madrasah merupakan terobosan baru Kementerian Agama dalam pengembangan dalam bidang Pendidikan. Harapannya dengan aplikasi tersebut Madrasah menjadi lebih baik dengan diimbangi melalui teknologi yaitu E-Learning. Dengan Website ELearning Madrasah ini memungkinkan Guru dan Siswa melakukan pembelejaran interaktif. Baik itu dalam tatap muka atau tidak. Melainkan dengan pembelajaran Online yang tidak harus bertatap muka. Dalam Website Elearning Madrasah tidak hanya proses pembelajaran saja yang dapat dilakukan. Tetapi juga bisa untuk Guru Bimbingan Konseling, semua termuat dalam Website Elearning Madrasah. ${ }^{6}$

Website Elearning Madrasah adalah sebuah aplikasi gratis produk Madrasah yang ditujukan untuk menunjang proses pembelajaran di Madrasah dari mulai Madrasah Ibtidayah (MI), Madrasah Tsanawiyah (MTs) dan Madrasah Aliyah (MA), agar lebih terstruktur, menarik dan interaktif. E-learning Madrasah memiliki 6 role akses diantaranya : (1) Operator Madrasah (Administrator), (2) Guru Mata Pelajaran, (3) Guru Bimbingan Konseling, (4) Wali Kelas, (5) Siswa, (6) Supervisor (Kepala Madrasah dan jajarannya).

6 Tim IT Dirjen Pendis, Buku Petunjuk Penggunaan Website E-Learning Madrasah, (Jakarta: Kementerian Agama, 2020), h. 4 
Pembelajaran menggunakan Website Elearning madrasah ini bisa dilakukan di sekolah atau di rumah bahkan kita sedang di luar asalkan ada terhubung dengan jaringan internet. Setiap belajar menggunakan Website Elearning madrasah guru dan siswa dapat melihat materi dan tugas belajar pada setiap hari yang terjadwalkan. Untuk mengaksesnya dengan cara masuk ke browser pada perangkat komputer maupun handphone, bisa menggunakan Mozila Firefox, Google Chrome, browser yang ada seperti Uc,Google dll. Selanjutnya Ketik link http://madrasah.kemenag.go.id/elearning di jendela browser lalu tekan enter. Akan muncul tampilan awal dari website e-learning madrasah, seperti gambar 1 di bawah ini:

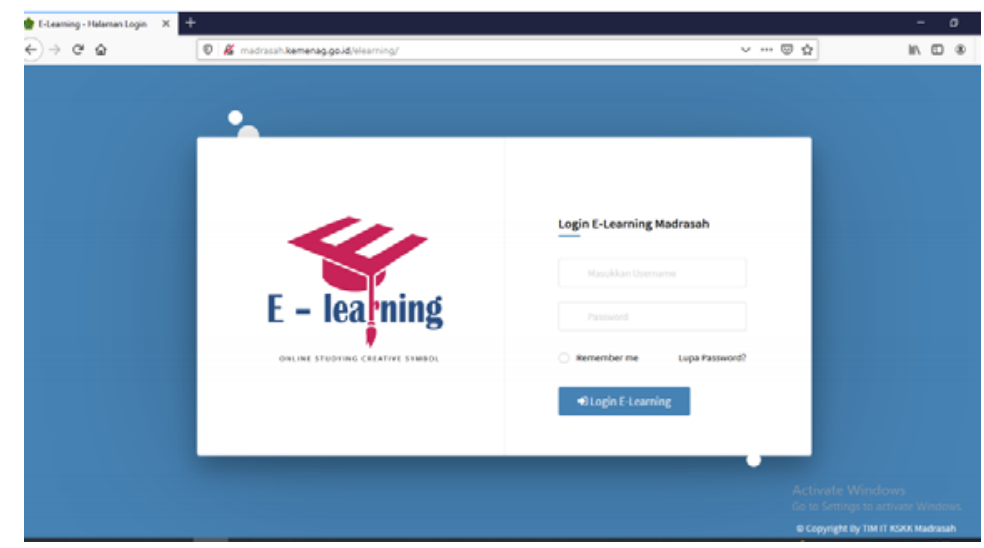

Gambar 1. Tampilan Awal website e-learning madrasah

Aplikasi elearning madrasah hanya dapat digunakan oleh operator madrasah, guru, siswa, dan wali kelas yang telah memiliki akun elearning madrasah. Setelah memiliki akun, pengguna aplikasi login melalui halaman utama elearning madrasah. Berikut merupakan langkah-langkah login aplikasi: (1) Buka halaman website elearning (2) Ketik NSM dan password (3) Klik login Elearning, akan tampil seperti gambar 2 di bawah ini: 


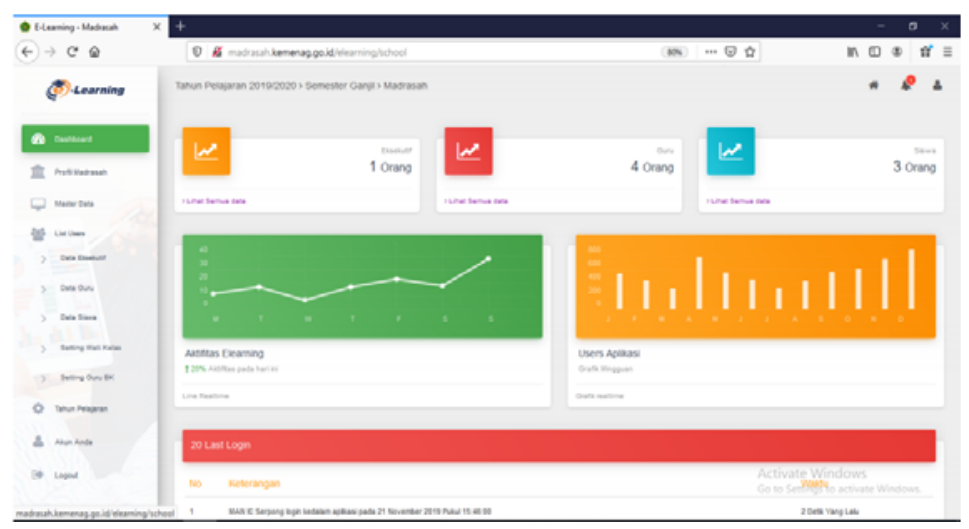

Gambar 2. Tampilan website e-learning madrasah

Pengertian hasil belajar menurut Richardo dan Rini ialah suatu akumulasi pembelajaran yang diperoleh siswa selama proses pembelajaran. ${ }^{7}$ Hasil belajar merupakan tujuan pendidikan yang dilaksanakan dalam proses pembelajaran sehingga siswa dapat mengetahui, memahami, serta mengaplikasikan pengetahuan yang diterima. Menurut Sudjono ${ }^{8}$, menyatakan bahwa hasil belajar adalah sebuah tindakan evaluasi yang dapat mengungkapkan aspek proses berpikir, juga dapat mengungkapkan aspek kejiwaan lainnya seperti aspek nilai atau sikap dan aspek keterampilan yang melekat pada diri siswa itu sendiri. Menurut S Nasution, hasil belajar adalah suatu perubahan yang terjadi pada individu yang belajar, bukan saja perubahan mengenai pengetahuan, tapi pengetahuan untuk membentuk kecakapan, kebiasaan, sikap, pengertian, penguasaan dan penghargaan dalam diri individu yang

${ }^{7}$ Richardo, \& Rini Intansari M. 2017. Impak Minat dan Motivasi Belajar terhadap Hasil Belajar Siswa, Vol 2 No. 2, (Bandung: Jurnal Pendidikan Manajemen Perkantoran, 2017), h.193

${ }^{8}$ Sudjono, A. Pengantar Evaluasi Pendidikan, (Jakarta: PT. Raja Grafindo Persada, 2012), h. 32 
belajar. ${ }^{9}$ Hal ini menjelaskan bahwa melalui hasil belajar dapat terungkap secara holistik penggambaran pencapaian siswa setelah melalui kegiatan pembelajaran.

Berdasarkan data-data yang diperoleh di awal, peneliti akan membahas sejauh mana pengaruh pembelajaran fisika secara online berbasis Website Elearning madrasah terhadap hasil belajar fisika siswa kelas X MIA MAN 2 Kota Palu. Adanya temuan masalah terkait pembelajaran adalah terjadi selama masa pandemi covid-19 yang mewajibkan seluruh siswa belajar dari rumah. Hal ini yang mengharuskan seluruh siswa tetap mengikuti proses pembelajaran walaupun tidak berada di sekolah. Pembelajaran secara daring menggunakan aplikasi Website Elearning madrasah adalah salah satu solusi tepat yang dapat dilakukan oleh guru serta siswa di tengah masa pandemi akibat virus covid-19.

\section{Metode Penelitian}

Penelitian ini merupakan penelitian kuantitatif dengan format deskriptif. Penelitian kuantitatif deskriptif adalah sebuah penelitian yang mempunyai tujuan untuk memberikan sebuah penjelasan terhadap sebuah kondisi atau bisa karena berbagai variabel yang timbul di masyarakat yang menjadi objek penelitian berdasarkan pada fenomena yang terjadi, kemudian data yang didapat diolah dengan menggunakan aplikasi SPSS. Salah satu software yang bisa digunakan untuk mengolah data dan menganalisis data yaitu SPSS (Statistical Package for the Social Sciences). SPSS yaitu software khusus untuk pengolahan data statistik yang paling populer dan paling banyak digunakan di seluruh dunia. SPSS

${ }^{9}$ Darwyan Syah, dkk. Strategi Belajar Mengajar, (Jakarta: Diadit Media, 2009), Cet. 1. H. 43 
dipakai dalam berbagai riset pasar, pengendalian dan perbaikan mutu (quality improvement), serta riset-riset sains. Kepopuleran SPSS ini dijadikan sebagai alat untuk pengolahan data. ${ }^{10}$

Menurut Rasimin, penelitian deskriptif menangkap ciri kas suatu obyek, seseorang, atau suatu kejadian pada waktu data dikumpulkan, dan ciri khas tersebut mungkin berubah dengan perkembangan waktu. ${ }^{11}$ Tapi hal ini bukan berarti hasil penelitian waktu lalu tidak berguna, dari hasilhasil tersebut kita dapat melihat perkemangan perubahan suatu fenomena dari masa ke masa.

Sampel dalam penelitian ini adalah siswa kelas X IPA1 MAN 2 Kota Palu tahun pelajaran 2020/2021 dengan jumlah siswa sebanyak 36 orang. Di dalam penelitian ini data yang digunakan adalah data primer dan data sekunder. Di dalam penelitan ini, data primer diperoleh melalui pengisian kuesioner oleh siswa kelas X IPA1 MAN 2 Kota Palu. Selain itu di dalam penelitian ini juga menggunakan wawancara namun hanya sebagai data pendukung dari data akurat hasil uji pendekatan kuantitatif. Sedangkan data sekunder diperoleh melalui jurnal-jurnal dan literatur yang ada di perpustakaan.

Teknik pengumpulan data melalui; (1) melalui angket atau kuesioner yang bertujuan untuk mencari informasi yang lengkap tentang sebuah kasus yang sedang diteliti. ${ }^{12}$ Respon dari angket-angket ini akan menghasilkan data mengenai pengaruh pembelajaran online berbasis Website Elearning Madrasah Terhadap Hasil Belajar Fisika Siswa Kelas

${ }^{10}$ Bungin, Burhan, Metodologi Penelitian Kuantitatif, (Jakarta: Prenada Media, 2005), h. 53

${ }^{11}$ Rasimin, Metodologi Penelitian, (Yogyakarta: Mitra Cendekia, 2018). h. 12

12 Susanti, Meilia Nur indah,Statistik Deskriptif dan induktik,(Yogyakarta:Graha ilmu,2010), h.17 
X IPA MAN 2 Kota Palu Tahun Ajaran 2020/2021. (2) melalui studi kapustakan diperoleh dari penelitan-penelitan sebelumnya, jurnal-jurnal, dan juga dari buku-buku di perpustakaan yang terkait dengan penelitian ini. (3) Peneliti melakukan wawancara kepada guru kelas X IPA MAN 2 Kota Palu mata pelajaran fisika terkait dengan pembelajaran online dan prestasi siswa selama pandemi Covid 19 ini terjadi. Namun wawancara ini hanyalah sebagai data pendukung. Menurut Sugiyono, kuesioner atau angket salah satu teknik pengumpulan data yang dilakukan dengan cara memberikan item-item atau pernyataan pertanyaan secara tertulis kepada responden untuk dijawabnya. ${ }^{13}$

Dalam penelitian ini menggunakan skala pengukuran interval dengan teknik skala likert. Skala likert adalah skala yang digunakan untuk mengukur sikap, pendapat, dan persepsi seseorang atau sekelompok orang tentang fenomena sosial. Dalam penelitian, fenomena sosial ini telah ditetapkan secara spesifik oleh peneliti yang selanjutnya disebut sebagai variabel penelitian. Pernyataan - pernyataan dalam angket akan digunakan teknik tertutup dengan skala likert, yaitu skala yang berisi lima tingkat prefensi jawaban, sebagai berikut $:^{14}$

13 Sugiyono, Metode Penelitian Kuantitatif, Kualitatif, dan R\&D, (Bandung: Alfabeta, 2018), h.142

14 Suzuki Syofian dkk, "Otomatisasi Metode Penelitian Skala Likert Berbasis Web", Vol.1 No.1, (Jakarta: jurnal.ftumj.ac.id, 2011), h.3 
Tabel 1. Skala Likert

\begin{tabular}{|c|c|c|}
\hline Simbol & Alternatif Jawaban & Nilai \\
\hline SS & Sangat Setuju & 5 \\
\hline S & Setuju & 4 \\
\hline CS & Cukup Setuju & 3 \\
\hline TS & Tidak Setuju & 2 \\
\hline STS & Sangat Tidak Setuju & 1 \\
\hline
\end{tabular}

Variabel Bebas pada penelitian ini adalah Pembelajaran Online berbasis website elearning madrasah (X). Pembelajaran online atau Elearning adalah pembelajaran yang disajikan dengan bantuan komputer. Huruf "e" dalam E-learning bermakna bahwa materi yang diberikan berbentuk digital sehingga dapat disimpan dalam perangkat elektonik. Elearning memberi ilustrasi bahwa dengan adanya teknologi informasi dan komunikasi, khususnya internet, pembelajaran menjadi lebih terbuka (open) dan fleksibel (flexible), terjadi kapan saja, dimana saja dan kepada siapa saja serta di lokasi mana saja. ${ }^{15}$

Variabel Terikat pada penelitian ini adalah hasil Belajar Fisika Siswa (Y). Hasil belajar merupakan kemampuan yang dimiliki siswa setelah mengalami pengalaman belajar dalam proses pembelajaran. Prestasi belajar ini pada hakekatnya yakni suatu hasil yang didapatkan oleh seseorang setelah melalui kegiatan belajar tertentu. Hasil belajar biasanya diberikan dalam bentuk angka, simbol, huruf, maupun kalimat. ${ }^{16}$

15 Bambang Warsita, "Pendidikan Jarak jauh: Perancangan, Pengembangan, Implementasi, dan Evaluasi Diklat, Cet. Pertama (Bandung: PT Remaja Rosdakarya, 2011), h. 136

${ }^{16}$ Khotimah, Khusnul, "Pengaruh Strategi Pembelajaran terhadap Hasil Belajar Ditinjau dari Aktivitas Belajar”, (Surakarta: Tiga Serangkai, 2016), h.14 
Pada penelitian ini, penulis menggunakan statistik deskriptif dengan menggunakan uji analisis regresi sederhana yaitu; Uji Validitas, Uji Reliabilitas dan Koefisien Determinasi $\left(\mathrm{R}^{2}\right)$. Validitas adalah suatu derajat ketepatan/kelayakan instrumen yang digunakan untuk mengukur apa yang akan diukur. Cook dan Campbell menyatakan bahwa validitas adalah sebagai kondisi yang mendekati kebenaran atau kesalahan yang terdapat dalam inferensi, proposisi, atau kesimpulan. ${ }^{17}$

Tahapan yang dilakukan untuk melakukan uji validitas adalah sebagai berikut: ${ }^{18}$

1) Mendefinisikan secara operasional suatu konsep yang akan diukur

2) Melakukan pengujian pada beberapa responden

3) Mempersiapkan tabel tabulasi jawaban

4) Menghitung nilai korelasi antara masing-masing skor butir jawaban dengan skor total dan butir jawaban.

5) Mengolah data dengan menggunakan rumus spss

6) Apabila nilai r-hitung lebih besar dari nilai r-tabel maka hasilnya adalah valid

7) Apabila r-hitung lebih kecil dari nilai r-tabel maka hasilnya tidak valid

8) Apabila nilai $p<0,005$ maka dikatakan valid

9) Apabila nilai $p>0,005$ maka dikatakan tidak valid

Suatu instrumen dapat memiliki kepercayaan yang tinggi jika hasil dari pengujian test /instrumen tersebut menunjukkan hasil yang tetap.

${ }^{17}$ Sarwono, Jonathan, "Rumus-Rumus Populer dalam SPSS 22 untuk Riset Skripsi”, (Yogyakarta: CV Andi, 2015) h. 247

${ }^{18}$ Setyawan, Dodiet Aditya, “Uji Validitas dan Reliabilitas instrumen Penelitian”, (Surakarta: Poltekkes Kemenkes Surakarta, 2014), h. 2 
Kuesioner penelitian setelah dilakukan uji reliabilitas dikatakan reliabel apabila nilai alpha minimal adalah 0.6. ${ }^{19}$

Koefisien Determinasi $\left(\mathrm{R}^{2}\right)$ digunakan untuk mengetahui dan mengukur seberapa jauh kemampuan sumbangan pengaruh variabel independen secara serentak terhadap variabel dependen. Nilai yang mendekati angka satu berarti variabel-variabel independent memberikan hampir semua informasi yang dibutuhkan untuk memprediksi variasi dependent.

\section{Pembahasan}

Tabel 2. Responden Berdasarkan Jenis_Kelamin

\begin{tabular}{|llr|r|r|r|}
\hline & & Frequency & Percent & Valid Percent & $\begin{array}{c}\text { Cumulative } \\
\text { Percent }\end{array}$ \\
\hline Valid & $\mathrm{L}$ & 13 & 36.1 & 36.1 & 36.1 \\
\cline { 2 - 6 } & $\mathrm{P}$ & 23 & 63.9 & 63.9 & 100.0 \\
\cline { 2 - 6 } & Total & 36 & 100.0 & 100.0 & \\
\hline
\end{tabular}

Dari data di atas didapat hasil bahwa jumlah responden terdiri dari 13 orang laki-laki atau $36,1 \%$ dan 23 orang perempuan atau $63,9 \%$.

Tabel 3. Responden Berdasarkan Umur

\begin{tabular}{|ll|r|r|r|r|}
\hline & Frequency & Percent & Valid Percent & \multicolumn{2}{c|}{$\begin{array}{c}\text { Cumulative } \\
\text { Percent }\end{array}$} \\
\hline Valid & 15 & 2 & 5.6 & 5.6 & 5.6 \\
\cline { 2 - 6 } & 16 & 27 & 75.0 & 75.0 & 80.6 \\
\cline { 2 - 6 } & 17 & 7 & 19.4 & 19.4 & 100.0 \\
\cline { 2 - 6 } & Total & 36 & 100.0 & 100.0 & \\
\hline
\end{tabular}

${ }^{19}$ Ibid, h. 248 
Berdasarkan data diatas didapat hasil bahwa responden terdiri dari beberapa lapisan umur, yaitu 15-17 tahun dengan jumlah sebagai berikut : 15 tahun : 2 orang, 16 tahun: 27 orang, dan 17 tahun sebanyak 7 orang.

Untuk menguji apakah setiap variabel yang digunakan dalam penelitian memenuhi syarat alat ukur yang baik atau tidak digunakan uji validitas. Apabila instrumen penelitian memenuhi sifat valid dan reliabel maka dikatakan baik, dan begitu pula sebaliknya. Apabila nilai p0,005 maka dikatakan tidak valid. Hasil olah data dengan menggunakan spss 25.0 adalah sebagai berikut :

Dari hasil uji penghitungan spss diperoleh rtabel dan rhitung sebagai berikut :

Tabel 4. Rtabel Rhitung

\begin{tabular}{|c|c|c|}
\hline $\begin{array}{c}\text { Nomor } \\
\text { Pertanyaan }\end{array}$ & $\mathrm{r}_{\text {hitung }}$ & $\mathrm{r}_{\text {tabel }}$ \\
\hline 1 & 0,635 & 0,3291 \\
\hline 2 & 0,576 & 0,3291 \\
\hline 3 & 0,754 & 0,3291 \\
\hline 4 & 0,525 & 0,3291 \\
\hline 5 & 0,525 & 0,3291 \\
\hline 6 & 0,576 & 0,3291 \\
\hline 7 & 0,754 & 0,3291 \\
\hline 8 & 0,525 & 0,3291 \\
\hline 9 & 0,717 & 0,3291 \\
\hline 10 & 0,754 & 0,3291 \\
\hline 11 & 0,556 & 0,3291 \\
\hline 12 & 0,601 & 0,3291 \\
\hline 13 & 0,556 & 0,3291 \\
\hline 14 & 0,717 & 0,3291 \\
\hline 15 & 0,748 & 0,3291 \\
\hline
\end{tabular}


Dari hasil pengujian dapat dilihat bahwa nilai sig.(2-tailed) setiap variabel $\mathrm{X}$ dan variabel $\mathrm{Y}$ adalah $<0,005$. Dilihat dari nilai $\mathrm{r}_{\text {hitung }}$ dan $\mathrm{r}_{\text {tabel }}$ didapat hasil bahwa nilai $r_{\text {hitung }}>r_{\text {tabel. }}$. Nilai $r_{\text {tabel }}$ 0,3291 diperoleh dari nilai $\mathrm{N} 36-2=34$. Angka 34 mempunyai nilai $\mathrm{r}_{\text {tabel }} 0,3291$. Maka dapat ditarik kesimpulan bahwa setiap indikator dari variabel X dan Y adalah valid sehingga data yang digunakan dapat dipergunakan pada tahap selanjutnya.

Uji reliabilitas kuesioner dilakukan setelah melakukan uji validitas. Apabila seluruh pertanyaan sudah valid baru dilakukan uji reabilitas. Variabel dikatakan lolos uji reabilitas apabila nilai cronbach's alphanya $>0,60$.

Tabel 5. Uji Reabilitas Variabel X

Reliability Statistics

\begin{tabular}{|c|c|c|}
\hline $\begin{array}{c}\text { Cronbach's } \\
\text { Alpha }\end{array}$ & $\begin{array}{c}\text { Cronbach's } \\
\text { Alpha Based on } \\
\text { Standardized } \\
\text { Items } \\
\end{array}$ & $\mathrm{N}$ of Items \\
\hline .957 & .956 & 10 \\
\hline
\end{tabular}

Tabel 6. Uji Reabilitas Variabel Y

Reliability Statistics

\begin{tabular}{|r|r|r|}
\hline $\begin{array}{c}\text { Cronbach's } \\
\text { Alpha }\end{array}$ & $\begin{array}{c}\text { Cronbach's } \\
\text { Alpha Based on } \\
\text { Standardized } \\
\text { Items }\end{array}$ & N of Items \\
\hline .909 & .912 & 5 \\
\hline
\end{tabular}

Dari hasil uji reliabilitas dapat diketahui bahwa secara keseluruhan variabel $\mathrm{X}$ dan Y memiliki nilai cronbach's alpha $>0,06$ yaitu sebagai berikut : 
1. Variabel $\mathrm{X}$ dengan nilai 0,957

2. Variabel Y dengan nilai 0,909

Dengan demikian dapat ditarik kesimpulan bahwa desain pertanyaan kuesioner pada variabel pembelajaran online berbasis website elearning madrasah dan hasil belajar siswa adalah reliabel.

Dengan menggunakan SPSS 25,0 mencari nilai adjusted $\mathrm{R}^{2}$. Semakin nilainya mendekati angka 1 berarti bahwa variabel-variabel independen memberikan hampir semua informasi yang dibutuhkan untuk memprediksi variabel dependen.

\section{Tabel 7. Model Summary}

\begin{tabular}{|ll|r|r|r|}
\hline Model & R & R Square & \multicolumn{1}{c|}{$\begin{array}{c}\text { Adjusted R } \\
\text { Square }\end{array}$} & $\begin{array}{c}\text { Std. Error of } \\
\text { the Estimate }\end{array}$ \\
\hline 1 & $.926^{\mathrm{a}}$ & .857 & .853 & .370 \\
\hline
\end{tabular}

a. Predictors: (Constant), $\mathrm{X}$

Dari data di atas dapat dilihat bahwa nilai $\mathrm{R}^{2}$ adalah 0,857 yang berarti bahwa variabel independen (pembelajaran online berbasis website elearning madrasah) mampu menjelaskan variabel dependen (hasil belajar siswa) sebesar $85,7 \%$ dan selebihnya $14,3 \%$ ditentukan atau dijelaskan oleh variabel lain yang tidak dijelaskan dalam penelitian ini.

Hasil wawancara dengan guru mata pelajaran fisika kelas X MAN 2 Kota Palu, menyatakan bahwa hasil belajar siswa masih baik walaupun kegiatan belajar mengajar dilakukan dengan metode daring selama pandemi Covid-19 ini. Hal ini membuktikan bahwa pembelajaran online mempunyai pengaruh positif terhadap hasil atau nilai yang didapat oleh siswa. 


\section{Penutup}

Dapat disimpulkan bahwa terdapat pengaruh yang signifikan antara pembelajaran online berbasis website elearning madrasah dengan hasil belajar fisika siswa. Nilai sig.(2-tailed) setiap variabel $\mathrm{X}$ dan variabel Y adalah $<0,005$. Dilihat dari nilai rhitung dan rtabel didapat hasil bahwa nilai rhitung $>$ rtabel. Nilai rabel 0,3291 diperoleh dari nilai N 36-2 = 34. Angka 34 mempunyai nilai $\mathrm{r}_{\text {tabel }} 0,3291$. Variabel $\mathrm{X}$ dan $\mathrm{Y}$ memiliki nilai cronbach's alpha $>0,06$. Variabel $\mathrm{X}$ dengan nilai 0,957 Variabel $Y$ dengan nilai 0,909 sehingga dikatakan reliabel. Nilai R2 adalah 0,857 yang berarti bahwa variabel independen (pembelajaran online) mampu menjelaskan variabel dependen (hasil belajar fisika siswa) sebesar 85,7\% dan selebihnya $14,3 \%$ ditentukan atau dijelaskan oleh variabel lain yang tidak dijelaskan dalam penelitian ini.

H1 diterima yaitu "terdapat pengaruh pembelajaran online berbasis website elearning madrasah terhadap hasil belajar fisika siswa kelas X IPA MAN 2 Kota Palu tahun ajaran 2020/2021. Didapat hasil bahwa pembelajaran online berbasis website elearning madrasah terbukti menghasilkan hasil belajar fisika siswa. Guru Mata pelajaran Fisika kelas X IPA MAN 2 Kota Palu, ketika dilakukan wawancara oleh peneliti mengatakan bahwa pembelajaran online sangatlah berbeda jauh dengan tatap muka, tetapi setidaknya dengan pembelajaran online berbasis website elearning madrasah ini dengan pendampingan orang tua maka tetap mendapatkan hasil belajar fisika siswa dengan baik. 


\section{DAFTAR PUSTAKA}

Agus Purwanto, dkk. Studi Eksploratif Dampak Pandemi COVID-19 Terhadap Proses Pembelajaran Online di Sekolah Dasar. Journal of Education, Phychology and Counseling, Vol 2 No.1. 2020.

Arifin, Zainal. Evaluasi Pembelajaran. Bandung: PT. Remaja Rosdakarya. 2012.

Bambang Warsita. Pendidikan Jarak jauh: Perancangan, Pengembangan, Implementasi, dan Evaluasi Diklat. Cet. Pertama. Bandung: PT Remaja Rosdakarya. 2011.

Burhanuddin, dkk. Merajut Asa Di Tengah Pandemi Covid-19 (Pandangan Akademisi UNHAS). Deepublish: Yogyakarta. 2020.

Darwyan Syah, dkk. Strategi Belajar Mengajar. Jakarta: Diadit Media. Cet. 1. 2009.

Dini Oktarika. Pengaruh Pembelajaran Menggunakan Media E-Learning Terhadap Minat Belajar Mahasiswa Pada Mata Kuliah E-Learning Di Program Studi P.TIK. Jurnal Pendidikan Informatika dan Sains. Vol 4 No. 1. 2015.

Jeffrey Payung Langi, Pengaruh Pembelajaran Fisika Secara Online Berbasis Zoom Meeting Terhadap Hasil Belajar Mahasiswa, Vol.16 No.2, Maluku: Jurnal Syntax Admiration, 2020

Khotimah, Khusnul. Pengaruh Strategi Pembelajaran terhadap Hasil Belajar Ditinjau dari Aktivitas Belajar. Surakarta: Tiga Serangkai. 2016.

Kompri. Belajar dan Faktor-Faktor yang Mempengaruhinya. Yogyakarta: Media Akademi. 2017.

Rasimin. Metodologi Penelitian. Yogyakarta: Mitra Cendekia. 2018.

Richardo, \& Rini Intansari M. Impak Minat dan Motivasi Belajar terhadap Hasil Belajar Siswa. Jurnal Pendidikan Manajemen Perkantoran Vol 2 No. 2. 2017

Sarwono, Jonathan. Rumus-Rumus Populer dalam SPSS 22 untuk Riset Skripsi. Yogyakarta: CV Andi. 2015. 
Setyawan, Dodiet Aditya. Uji Validitas dan Reliabilitas instrumen Penelitian. Surakarta: Poltekkes Kemenkes Surakarta. 2014.

Sudjono A. Pengantar Evaluasi Pendidikan. Jakarta: PT. RajaGrafindo Persada. 2012.

Susanti, Meilia Nur indah. Statistik Deskriptif dan induktik. Yogyakarta: Graha ilmu. 2010.

Suzuki Syofian, dkk. Otomatisasi Metode Penelitian Skala Likert Berbasis Web. Vol.1 No.1. Jakarta: jurnal.ftumj.ac.id. 2011.

Tim IT Dirjen Pendis. Buku Petunjuk Penggunaan Website E-Learning Madrasah. Jakarta: Kementerian Agama RI. 2020.

Wilson, A., \& Informatika, P. S. Penerapan Metode Pembelajaran Daring (Online) Melalui Aplikasi Berbasis Android Saat Pandemi. Sap (Susunan Artikel Pendidikan). 2020. 